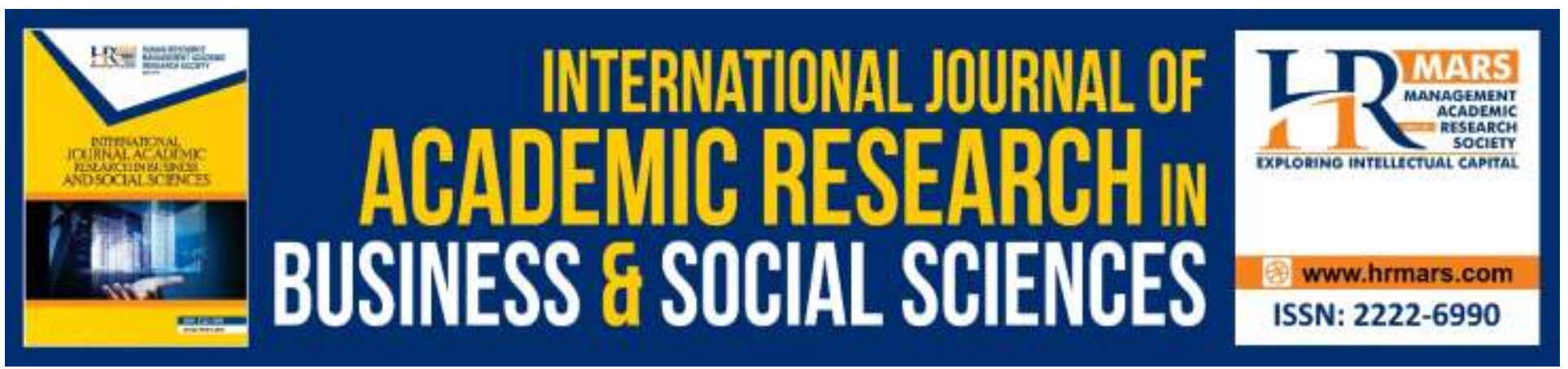

\title{
Analysis of the Integration between Islamic and Conventional Stocks Market in Malaysia
}

\author{
Ahmad Tarmizi Al Shaari, Mohd Yahya Mohd Hussin
}

To Link this Article: http://dx.doi.org/10.6007/IJARBSS/v9-i7/6114

DOI: $10.6007 /$ IJARBSS/v9-i7/6114

Received: 12 May 2019, Revised: 18 June 2019, Accepted: 03 July 2019

Published Online: 23 July 2019

In-Text Citation: (Shaari, 2019)

To Cite this Article: Shaari, A. T. Al. (2019). Analysis of the Integration between Islamic and Conventional Stocks Market in Malaysia. International Journal of Academic Research in Business and Social Sciences, 9(7), 259272.

Copyright: (C) 2019 The Author(s)

Published by Human Resource Management Academic Research Society (www.hrmars.com)

This article is published under the Creative Commons Attribution (CC BY 4.0) license. Anyone may reproduce, distribute, translate and create derivative works of this article (for both commercial and non-commercial purposes), subject to full attribution to the original publication and authors. The full terms of this license may be seen

at: http://creativecommons.org/licences/by/4.0/legalcode

Vol. 9, No. 7, 2019, Pg. 259 - 272

http://hrmars.com/index.php/pages/detail/IJARBSS

JOURNAL HOMEPAGE

Full Terms \& Conditions of access and use can be found at http://hrmars.com/index.php/pages/detail/publication-ethics 


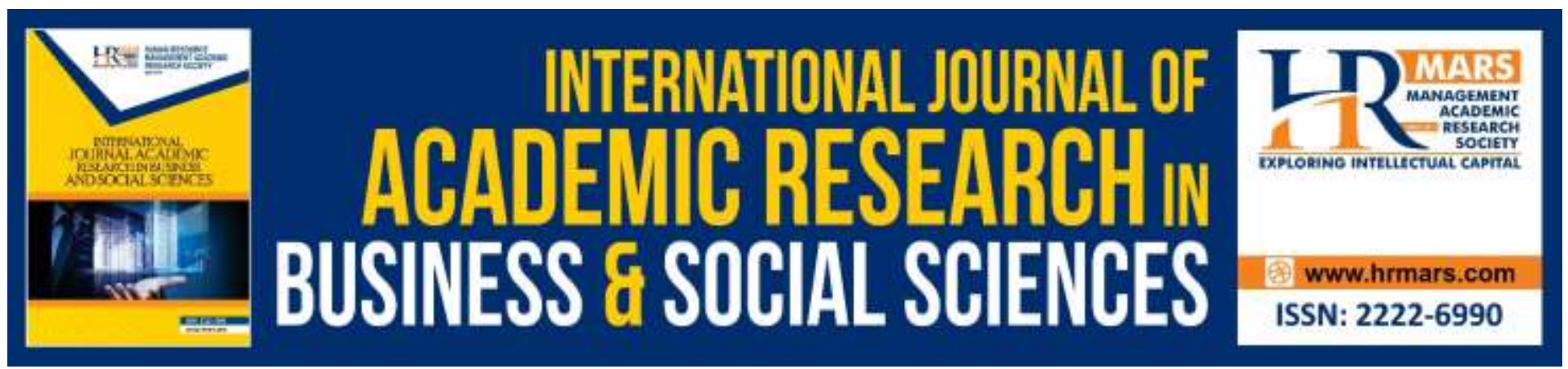

\title{
Analysis of the Integration between Islamic and Conventional Stocks Market in Malaysia
}

\author{
Ahmad Tarmizi Al Shaari, Mohd Yahya Mohd Hussin \\ Faculty of Management \& Economics, Universiti Pendidikan Sultan Idris, 35900, Tanjong Malim, \\ Perak \\ Email: yahya@fpe.upsi.edu.my
}

\begin{abstract}
This paper investigates the integration between Islamic and Conventional Stock Markets in Malaysia. The study focuses on three key indices to represent the stock markets in Bursa Malaysia which is FTSE Emas Syariah Index (FBMESI), FTSE Kuala Lumpur Composite Index (FBMKLCI) and FTSE Ace Index (FBMAI). This study uses monthly data from January 2009 to December 2015 and applies the Johansen and Juselius co-integration tests as well as Vector Error Correction Model (VECM) in order to determine the form of relationship between this three indices. The findings show that there is a positive and significant long-term relationship between the Islamic stock market and the conventional stock market in Bursa Malaysia. In addition, there is also have integration between stocks in Main markets and the Ace market. While for short-term causal relationships, $\mathrm{FBMKLCl}$ is the cause of granger to FBMESI but not to FBMAI while FBMESI is the cause of short-term granger to FBMAI.
\end{abstract}

Keywords: Integration of Stock Market, Islamic Capital Market, Long Term Relationship, Short Term Granger Causality, VAR, VECM

\section{Introduction}

Malaysia is the pioneer in development of Islamic finance in South-East Asia where concerted efforts have been taken by the government, central bank, regulators and market players. Over the past 30 years, Malaysia has built a strong and comprehensive framework to ensure the integrity of the shariah-compliant banking and finance system and it has inspired the Muslim community from other countries to emulate this initiative (Global Islamic Financial Report 2010). For example, the National Islamic Banking Act and the Takaful Act that were established in 1983 and 1984 to support and to ensure the effectiveness of financial system. At the end of year 2008, the shariah-compliant fund management industry in Malaysia has grown from just 2 Syariah unit trust funds in 1993 to 149 funds in 2008. This makes shariah-compliant unit trust funds increased to $26 \%$ of the total 579 funds in Bursa Malaysia with the net asset value of RM17.19 billion (Global Islamic Financial Report 2010). As an Islamic State, the existence of the Islamic Capital Market (ICM) in Malaysia is very significant in 
INTERNATIONAL JOURNAL OF ACADEMIC RESEARCH IN BUSINESS AND SOCIAL SCIENCES Vol. 9, No. 7, July, 2019, E-ISSN: 2222-6990 @ 2019 HRMARS

providing a capital-raising platform, fund mobilization and investment opportunity based on syariah principles to meet the demands of a comprehensive capital market (Hussin, Muhammad, Razak, Mahjom, Hadi, 2013). Based on this statement, the role of ICM is to complement the Islamic financial system in Malaysia and subsequently expand and enhance the investment in the Islamic financial market.

The Islamic and the Conventional Stock Market are the two stock market systems available in Malaysia where there are three main indices representing Islamic Stock Market and Conventional Stock Market traded in Main Board and ACE Board in Bursa Malaysia namely FTSE Emas Syariah Index (FBMESI), FTSE Kuala Lumpur Composite Index (FBMKLCI) and FTSE Ace Index (FBMAI). The variance shown of performance of this three indices shown as below:

Table 1: The developments of FBMESI, FBMKLCl and FBMAI indices from 2009 to 2015.

\begin{tabular}{|c|c|c|c|}
\hline Year & FBMESI & FBMKLCI & FBMAI \\
\hline December 2015 & $12,800.65$ & $1,692.51$ & $12,800.65$ \\
\hline December 2014 & $12,507.03$ & $1,761.25$ & $12,507.03$ \\
\hline December 2013 & $13,051.60$ & $1,866.96$ & $13,051.60$ \\
\hline December 2012 & $11,520.73$ & $1,688.95$ & $11,520.73$ \\
\hline December 2011 & $10,300.29$ & $1,530.73$ & $10,300.29$ \\
\hline December 2010 & $10,058.15$ & $1,518.91$ & $10,058.15$ \\
\hline December 2009 & $8,509.52$ & $1,272.78$ & $8,509.52$ \\
\hline
\end{tabular}

The data in table 1 show that the three indices experienced consistent growth between 2009 and 2013. However in 2014 all of these indices showed a decline while in 2015 only FBMESI and FBMAI recorded increases but not for $\mathrm{FBMKLCl}$ which experienced a downward trend. This also indicates that there are interesting performance issues to be investigated among the indices as they are traded in the same market in Bursa Malaysia but have different performances. Hence, the information of the integration between this three indices need be studied to assist investors, fund managers, and other market participants in making decisions on their investments and finances. Furthermore, this stock market integration will enable some important facts to be acquired and allow policy makers to develop effective market strategies and develop appropriate policies to ensure the financial markets in Malaysia remain competent and stable. Information on this integration is also important as it will help generating higher productivity and boost the economic growth by stimulating domestic investment and savings (Mohan 2005) and will also reduce capital costs in an integrated market as risk sharing between domestic and international economic activities (Tai, 2007).

\section{Literature Review}

The study on stock market integration has been widely practiced by previous researchers. Among the studies in analyzing the nature of market integration done previously are such as (Grubel 1968; Hanna 1999; Goldstein and Mussa 1993). They focusing on market integration studies among developed countries. Levy and Sarnat (1970) expanded the study by examining the integration between developed and developing countries markets. There are also many studies conducted in analyzing 
INTERNATIONAL JOURNAL OF ACADEMIC RESEARCH IN BUSINESS AND SOCIAL SCIENCES Vol. 9, No. 7, July, 2019, E-ISSN: 2222-6990 @ 2019 HRMARS

integration between the continent's stock market such as Wooi (2007) which studies the APEC market while Lee and Jeong (2014) was reviewing the integration of the North East Asian and European markets.

Apart from that, there are also many studies have been done on the integration of Islamic stock markets such as Marashdeh and Shrestha (2010) who investigated the market integration between the six GCC countries - United Arab Emirates, Bahrain, Saudi Arabia, Oman, Kuwait, Qatar with two advanced markets as in United States and Europe. While Hussin, Yusof, Muhammad, Razak, Hashim \& Marwan (2013) empirically studied the practice among Islamic stock markets in Malaysia, Indonesia and the rest of the world and also Kassim (2013) studied the effects of global financial crisis on seven selected Islamic stock markets. Marjan and Mansur (2014) did investigate the integration of Islamic stock markets conducted in Malaysia with US and Japanese developed stock markets and two developing Islamic stock markets in India and China. Auzairy, Ahmad, Ho and Sapian (2012) conducted a study to explore the relationship and level of stock market integration of Asian countries by focusing on Malaysia, Thailand, Indonesia and South Korea stock markets with world stock markets from January 1997 to December 2009. They used the correlation coefficient, univariate analysis regression, co-integration test, and autoregressive vector model (VAR) with Asian stock index and $\mathrm{MSCl}$ World Index. The empirical evidence from this study suggests that there is no long-term integration but there is a short-term integration of the Asian stock market with the world stock market. In addition, numerous findings and studies also made to compare the relationship of the Islamic State market and the developed country market to provide diversification investment information to investors such as by (Alexakis, Pappas and Tsikouras, 2015; Ramdhan, Mohamed Yousop, Ahmad \& Abdullah, 2016; Majdoub, Mansour \& Jouini, 2016).

Meanwhile, in the context of the integration of the stock market within a country, Wong and Zhang (2011) conducted a study on the integration of the three key stock markets in China. Iqbal, Rehana and Azeem (2013) conducted a study to look at the effects of the anomalous calendar on the Islamic and Conventional stock market in Pakistan, while Eun, Lee and Wang (2014) analyzed the level of domestic integration in the United States. Only Chan and Abd Karim (2005) have conducted an integration study among the five major economic sectors listed in the main board of Bursa Malaysia. Albaity and Ahmad (2009) tested the performance of the Islamic and Conventional stock market in Malaysia by incorporating both the composite index $(\mathrm{KLCl})$ and the Syariah index (KLSI) in their study. The results showed that no significant difference in the relationship between the returns with the risk for the period 1999 to 2005. In addition, they tested the short-term relationship for both indexes using the Causality Test and Johnson Co-Integration. The test results show that there is a short-term relationship between the two indexes that can be concluded that there is no diversity opportunity between the index and the movement of one index gives signal to the other index movement. Pranata and Nurzanah (2015) used Capital Asset Pricing Model (CAPM) method to assess the performance and instability of Islamic and conventional stock indexes together with variable determinants in Indonesia and found no significant difference in performance between JII and LQ45 while JII was less and uncertain of LQ45, except in 2010. In addition, JII's performance is less affected by external factors such as crude oil prices.

In the more recent research, which is also in line with the objectives of the present study, Umairah and Mansur (2017) investigated the dynamic relationship of regional conventional and 
Islamic stocks with the Malaysian Islamic stock market however they limit it to identify if the investment portfolio can be diversified. The results show that Bursa Malaysia's FTSE Bursa Syariah Emas Index has a low correlation with the global stock market index, regardless of conventional or Islamic. However, the correlation between Islamic stock markets is relatively high. Malaysian Islamic stock market investors who have allocated their investments to the global market can enjoy the benefits of diversified portfolios. These results also indicate that Malaysian Islamic stockholders could benefit from diversified portfolios in regional and international equity markets if they kept the correlation between stocks at different investment approaches.

\section{Methodology}

The data and variables in this research are taken from authoritative sources to ensure the analysis of the integration between the Islamic and Conventional stock market in Malaysia can be made. In order to achieve the objectives of the study, the data of FTSE Bursa Malaysia Emas Index (FBMESI), FTSE Bursa Malaysia KLCI (FBMKLCI) and FTSE Bursa Malaysia Ace Index (FBMAI) were used. The data were collected from various stock market organizations such as Bursa Malaysia, Bank Negara Malaysia Statement Reports and the Annual Report of the Securities Commission of Malaysia.

This study uses monthly time series data from January 2009 to December 2015 where such timeframes are sufficient to understand the integration of the two Islamic and conventional stock markets in Bursa Malaysia. The method approach used in this study was the approach of the standard Vector Autoregression (VAR) estimation method on the model that was formed. The reason to use this method because there are some studies in economics and finance that have been using this VAR budgeting method in addition to the methods of economic research and use the principles such as the smallest regression (OLS), auto regression (AR) and so on. Additionally, by using this VAR technique will able to produce Johansen and Juselius co-integration vector tests to see the relationship between the long term relation and the variables involved.

Moreover, the correlation test is used to see the relationship between the short and long term causes for variables also can be done through the VAR constraint model or known as the Vector Correction Vector Model (VECM).The model applied to look at the integration of Islamic and conventional stock markets is as follows:

$$
F B M E S_{t}: \alpha_{0}+\alpha_{1} F B K L C I_{t}+\alpha_{2} F B A I_{t}+\mu_{t}
$$

The equation will be used to view the integration of the FTSE Bursa Malaysia Emas Syariah Index (FBMESI) with FTSE Bursa Malaysia KLCI (FBKLCl) and FTSE Bursa Malaysia Ace Index (FBMAI) stock index based on Asset Pricing Model Capital (CAPM) that has been discussed previously.

The equation in the model below shows the relation of three variables according to the standard VAR budgeting method: 
INTERNATIONAL JOURNAL OF ACADEMIC RESEARCH IN BUSINESS AND SOCIAL SCIENCES Vol. 9, No. 7, July, 2019, E-ISSN: 2222-6990 @ 2019 HRMARS

$$
\left[\begin{array}{l}
F B M E S I_{t} \\
F B M K L C I_{t} \\
F B M A I_{t}
\end{array}\right]=\left[\begin{array}{l}
A_{1} \\
A_{2} \\
A_{3}
\end{array}\right]+R(L)\left[\begin{array}{l}
F B M E S I_{t-1} \\
F B M K L C I_{t-1} \\
F B M A I_{t-1}
\end{array}\right]+\left[\begin{array}{l}
e t_{1} \\
e t_{2} \\
e t_{3}
\end{array}\right]
$$

Where $A$ is an interception, et is a Gaussian error vector with a min of zero, $\Omega$ the variance matrix, $\mathrm{R}$ is $3 \times 3$ of the estimator parameter polynomial matrix, and $(L)$ is the latitude operator.

The method of data analysis in this study was using descriptive data analysis method and followed by integration test. After a series of periods tested with a nature of immobile, then the co-integration test was carried out using the Engle and Granger approaches (1987) and Johansen and Juselius (1990). Then the study continue by the Granger causality in shape of error correction vector model (VECM). After that, it was tested with a diagnostic test and ended with a testing of reaction \& variance decomposition and structural change test.

\section{Result}

Table 2 below provide the summary statistical conclusions on the descriptive tests made on the returns of the stock variables of this study. The mean value of the FBMESI variable recorded the highest value of 10636.53 followed by FBMAI at 4911.861 and FBMKLCI at 1520.861. FBMESI also has high return and highest volatility of 0.2040 which is commensurate to its return. The smallest risk experienced by $\mathrm{FBMKLCl}$ at 0.00267 . The divergence analysis found that FBMAl variables had a positive skewness value of data that was a tough right while the other variables FBMKLCI and FBMESI had negative deviations and the data was a lever to the left. All stock market have positives kurtois value where the highest value is $\mathrm{FBMKLCl}$ at 2.6300. This indicates that the distribution of stock market is leptokurtic than the normal distribution. The Jarque -Bera test rejects normality for all distribution.

Table 2: Descriptive Analysis

\begin{tabular}{|l|c|c|c|}
\hline & FBMESI & FBMKLCI & FBMAI \\
\hline Min & 10636.53 & 1520.698 & 4911.861 \\
\hline Median & 10886.74 & 1597.740 & 4550.535 \\
\hline Maxsimum & 13387.34 & 1882.710 & 7278.940 \\
\hline Minimum & 5853.460 & 863.6100 & 2942.670 \\
\hline Std. Deviation & 2040.106 & 267.5415 & 1056.098 \\
\hline Skewness & -0.626049 & -0.829178 & 0.509305 \\
\hline Kurtosis & 2.509514 & 2.930080 & 2.210924 \\
\hline Jarque-Bera & 8.438843 & 12.85683 & 7.747634 \\
\hline Probability & 0.014707 & 0.001615 & 0.020779 \\
\hline Total & 1191292. & 170318.2 & 550128.4 \\
\hline Sum Sq. Dev. & $4.62 \mathrm{E}+08$ & 7945211. & $1.2 \mathrm{E}+08$ \\
\hline Observation & 112 & 112 & 112 \\
\hline
\end{tabular}


INTERNATIONAL JOURNAL OF ACADEMIC RESEARCH IN BUSINESS AND SOCIAL SCIENCES

Vol. 9, No. 7, July, 2019, E-ISSN: 2222-6990 @ 2019 HRMARS

Table 3 summarizes the results of both Augumented Dickey Fuller (ADF) and Philip Perron (PP) tests for all variable. As per shown below, the null hypothesis of non-stationary for the ADF and PP tests is accepted for all variables, indicating that all variables are non-stationary in level but become stationary after first differencing. Thus they are integrated of order 1 or I (1).

Table 3: Unit Root Test Results

\begin{tabular}{|l|c|c|c|c|c|c|c|c|}
\hline \multirow{2}{*}{ Test } & \multicolumn{3}{|c|}{ Augmented Dickey Fuller (ADF) } & \multicolumn{4}{c|}{ Philip Pheron (PP) } \\
\hline \multirow{2}{*}{ Variables } & \multicolumn{2}{|c|}{ Level } & \multicolumn{2}{c|}{ First Difference } & \multicolumn{2}{c|}{ Level } & \multicolumn{2}{c|}{ First Difference } \\
\cline { 2 - 9 } & Intercept & $\begin{array}{c}\text { Trend \& } \\
\text { Intercept }\end{array}$ & Intercept & $\begin{array}{c}\text { Trend \& } \\
\text { Intercept }\end{array}$ & Intercept & $\begin{array}{c}\text { Trend \& } \\
\text { Intercept }\end{array}$ & Intercept & $\begin{array}{c}\text { Trend \& } \\
\text { Intercept }\end{array}$ \\
\hline FBMESI & $\begin{array}{c}-0.7826 \\
(0)\end{array}$ & $\begin{array}{c}-2.1898 \\
(0)\end{array}$ & $\begin{array}{c}-9.5681^{*} \\
(0)\end{array}$ & $\begin{array}{c}-9.5405^{*} \\
(0)\end{array}$ & $\begin{array}{c}-0.9473 \\
(4)\end{array}$ & $\begin{array}{c}-2.4047 \\
(4)\end{array}$ & $\begin{array}{c}-9.6325^{*} \\
(3)\end{array}$ & $\begin{array}{c}-9.6045^{*} \\
(3)\end{array}$ \\
\hline FBMKLCl & $\begin{array}{c}-0.8532 \\
(0)\end{array}$ & $\begin{array}{c}-1.6512 \\
(0)\end{array}$ & $\begin{array}{c}-9.6321^{*} \\
(0)\end{array}$ & $\begin{array}{c}-9.5881^{*} \\
(0)\end{array}$ & $\begin{array}{c}-1.0755 \\
(5)\end{array}$ & $\begin{array}{c}-2.0521 \\
(6)\end{array}$ & $\begin{array}{c}-9.8342^{*} \\
(5)\end{array}$ & $\begin{array}{c}-9.7961^{*} \\
(3)\end{array}$ \\
\hline \multirow{2}{*}{ FBMAI } & -2.0575 & -3.2742 & $-6.5742^{*}$ & $-6.5783^{*}$ & -2.1274 \\
$(0)$ & $(2)$ & $\begin{array}{c}-3.2877 \\
(1)\end{array}$ & $\begin{array}{c}10.3373^{*} \\
(4)\end{array}$ & $\begin{array}{c}10.3115^{*} \\
(4)\end{array}$ \\
\hline
\end{tabular}

Note: *Denote significant at $1 \%$

The table above show the result of unit root test that have been performed based on the Augmented Dickey Fuller (ADF) and the results of the unit test conducted through Phillip Perrons (PP) for all variable. Implementation of the ADF and PP test is carried out after taking into account interception variable and time trends. Minimal Akaike Information Criterion (AIC) values are determined based on optimum latency of the ADF test. While the lag period selected based on the Newey-West bandwidth selection methodology. Based on the table 3, it shows that all FBMKLCI, FBMAI and FBMESI variables are non-stationary or all variable have unit root problem at the level of either interception or time trends interception. Based on that result, the ADF unit root test, the time series data is in still at the first differentiation stage and integrates in the first degree of integration I (1). It shows that all variables studied are in the still position or have no unit root problem at the level of interception and time trends. This finding proves that all variables are smaller with $p<0.05$ values than the predicted critical value of $p=0.05$. This statistical analysis shows that $t$ value is not significant. All variables involving intercept variables or bypass variables and time trends are in a stationary or significant position at the first differential level. While PP statistical analysis indicates that the value of $t$ for all variables at the first differential level is greater and significant than the predetermined critical $t$ value. The findings show that all variables are still at the first differentiation stage and integrate at the first degree of integration I (1) based on the PP unit root test, the time series data. The results of this study can indirectly support the findings of earlier ADF unit stillness tests. 
INTERNATIONAL JOURNAL OF ACADEMIC RESEARCH IN BUSINESS AND SOCIAL SCIENCES Vol. 9, No. 7, July, 2019, E-ISSN: 2222-6990 ¿ 2019 HRMARS

Table 4: Lag Length Test Results Based on the VAR Estimating Method

\begin{tabular}{|c|c|c|c|c|c|c|}
\hline Lag test & Log 1 & $\begin{array}{c}\text { Sequential } \\
\text { Modified } \\
\text { (SM) }\end{array}$ & $\begin{array}{c}\text { Final } \\
\text { Prediction } \\
\text { Error } \\
\text { (FPE) }\end{array}$ & $\begin{array}{c}\text { Akaike } \\
\text { Information } \\
\text { Criterion } \\
\text { (AIC) }\end{array}$ & $\begin{array}{c}\text { Schwarz } \\
\text { Information } \\
\text { Criterion } \\
\text { (SIC) }\end{array}$ & $\begin{array}{c}\text { Hannan- } \\
\text { Quinn } \\
\text { Information } \\
\text { Criterion } \\
\text { (HQ) }\end{array}$ \\
\hline $\mathbf{0}$ & -2289.718 & $\mathrm{Na}$ & $2.82 \mathrm{e}+15$ & 44.09074 & 44.16702 & 44.12164 \\
\hline $\mathbf{1}$ & -1886.126 & 776.1403 & $1.43 e+12^{*}$ & $36.50241^{*}$ & $36.80754^{*}$ & $36.62603^{*}$ \\
\hline $\mathbf{2}$ & -1883.120 & 5.606977 & $1.61 \mathrm{e}+12$ & 36.61769 & 37.15165 & 36.83401 \\
\hline $\mathbf{3}$ & -1878.463 & 8.418083 & $1.75 \mathrm{e}+12$ & 36.70121 & 37.46401 & 37.01024 \\
\hline
\end{tabular}

Note: * The lag value chosen by the criteria is based on the minimum value

Based on table 4 above, Final Prediction Error (FPE), Sequential Modified LR Test Statistic (LR), Akaike Information Criterion (AIC), Hannan-Quinn Information Criterion (HQ) and Schwarz Information Criterion (SIC) have selected lag 1 for the smallest value for each criterion. Based on the findings shown in Table 4 above, this study only used the Akaike Information Criterion (AIC) as the lag period obtained is 1 . The selection of lag period that using this criterion in their previous study was like Adam and Tweneboah (2008) and Yusof, Majid and Razali (2006). Hence, the use of subsequent analysis based on cointegration tests and Vector Error Correction Model (VECM) tests will takes into account only lag 1.

Table 5: VAR Stability Test

\begin{tabular}{|l|l|}
\hline \multicolumn{1}{|c|}{ Root } & \multicolumn{1}{c|}{ Modulus } \\
\hline 0.961414 & 0.961414 \\
\hline $0.940546-0.012978 \mathrm{i}$ & 0.940636 \\
\hline $0.940546+0.012978 \mathrm{i}$ & 0.940636 \\
\hline-0.165124 & 0.165124 \\
\hline 0.085971 & 0.085971 \\
\hline-0.031672 & 0.031672 \\
\hline
\end{tabular}

Table 5 above shows the result of test of all roots of the polynomial function are absolute values smaller than one and are in the circle unit. The finding show that the VAR model is stable. 
INTERNATIONAL JOURNAL OF ACADEMIC RESEARCH IN BUSINESS AND SOCIAL SCIENCES

Vol. 9, No. 7, July, 2019, E-ISSN: 2222-6990 @ 2019 HRMARS

Table 6: Johansen dan Juselius Co-Integration Test Results

\begin{tabular}{|c|c|c|c|c|c|c|c|c|}
\hline Model & $\begin{array}{c}\text { Null } \\
\text { Hypothe } \\
\text { sis }\end{array}$ & $\begin{array}{c}\text { Statistic } \\
\text { Trace }\end{array}$ & $\begin{array}{c}\text { Critical } \\
\text { Value } \\
(5 \%)\end{array}$ & $\begin{array}{c}\text { Maximum } \\
\text { Eigen } \\
\text { Statistic } \\
\text { Trace }\end{array}$ & $\begin{array}{c}\text { Critical } \\
\text { Value } \\
(5 \%)\end{array}$ & Variables & $\begin{array}{c}\text { Long Term } \\
\text { Coefficient } \\
\text { Elasticity }\end{array}$ & Results \\
\hline \multirow{2}{*}{$\begin{array}{c}\text { Lag } \\
\text { Length: } 1\end{array}$} & $r \leq 0$ & $\begin{array}{c}129.6828 \\
*\end{array}$ & 29.7970 & $56.3006 *$ & 21.1316 & FBMESI & 1.0000 & \begin{tabular}{c} 
Statistical \\
Trace \\
\cline { 2 - 9 }
\end{tabular} \\
\cline { 2 - 9 } & $r \leq 2$ & 2.66655 & 3.8414 & 2.6665 & 3.8414 & FBMAl & -0.0770 & $\begin{array}{c}\text { Showed in } \\
\text { a 2-way } \\
\text { co- } \\
\text { integratio } \\
n\end{array}$ \\
\hline
\end{tabular}

Note. ${ }^{*}$ Denote Significant at $5 \%$

Critical Value Based on Osterwald-Lenum (1992)

Table 6 above shows the result of cointegration test using lag period 1. The findings show that there are at least two co-integrated vector relationships in the model used in this study. This finding also shows the null hypothesis that there is no co-integration vector $(r \leq 1)$, the statistic trace (73.382) is greater than the critical value (15.494) and significant at the level $p<.05$. Based on the max-eigen test, there was a co-integration vector in all variables following the statistical value of Eigan Max found to be bigger than the critical value of Osterwald-Lenum at the significance level $p=05$. The zero hypothesis found that there is no co-integration vector $(r \leq 1)$, the statistic value of Eigan Max (44.715) is bigger than the critical value (14.264) and is significant at the significance level p 0.05. In conclusion, the analysis using the Johansen and Juselius co-integration tests can prove that there are at least two (2) vectors in a conjointly integrated model. The results showed that there was a significant long-term relationship between the variables studied. The results showed that there was a significant long-term relationship between the variables studied. These findings have been able to answer the first to the third hypothesis for this study. The findings also coincide with the findings of the study by Majdoub, Mansour and Jouini (2016) identified the integration of market prices between long-term conventional and Islamic stocks in France, Indonesia, the United Kingdom and United States. 
INTERNATIONAL JOURNAL OF ACADEMIC RESEARCH IN BUSINESS AND SOCIAL SCIENCES

Vol. 9, No. 7, July, 2019, E-ISSN: 2222-6990 @ 2019 HRMARS

Table 7: Co-integration Relationship $t$ Test

\begin{tabular}{|l|l|l|l|}
\hline \multirow{2}{*}{$\begin{array}{l}\text { Dependent } \\
\text { Variable } \\
\text { (FBMESI) }\end{array}$} & \multicolumn{2}{|l|}{ Independent Variables } & \\
\cline { 2 - 4 } & FBMKLCI & FBMAI & C \\
\hline Coefficient & 1.0143 & 0.0770 & -0.000296 \\
\hline$t$ value & 23.4634 & 3.0889 & \\
\hline
\end{tabular}

Note: Significant at $1 \%$ respectively

The long term equation shows that FBMESI values are positively correlated with FBMKLCl. The results of the study based on the Johansen and Juselius co-integration tests have shown the long-term relationships between variables and successfully produced the following equations:

$\mathrm{FBMESI}=0.0002+1.01043 \mathrm{FBMKLCl}{ }^{*}+0.0770 \mathrm{FBMAI}^{*}$

The equation obtained from the test shows a positive and significant relationship between FBMESI and FBMAI and also FBMESI and FBMKLCl. The findings are similar to Darrat, Elkhal and Hakim (2000) which analyzed Egypt, Morocco and Jordan stock markets with the world's leading stock market of the United States and found that the Islamic stock market in that country did not integrate with the conventional stock market in the United States but integrated within the country.

Table 8: Vector Error Correlation Model (VECM) Result

\begin{tabular}{|c|c|c|c|c|}
\hline \multirow{2}{*}{$\begin{array}{c}\text { Dependent } \\
\text { Variables }\end{array}$} & \multicolumn{3}{|c|}{ Independent Variables } & \multirow{2}{*}{ T - Statistic } \\
\cline { 2 - 5 } & $\Delta \mathrm{FBMESI}$ & $\Delta \mathrm{FBMKLCl}$ & $\Delta \mathrm{FBMAI}$ & Ect-1 \\
\hline \multirow{2}{*}{$\Delta \mathrm{FBMESI}$} & & $8.0169^{*}$ & 0.0028 & $-1.5663^{*}$ \\
& & $(0.0046)$ & $(0.9577)$ & {$[-4.0290]$} \\
\hline \multirow{2}{*}{$\Delta \mathrm{FBMKLCl}$} & 0.0161 & & 0.8148 & -0.13046 \\
& $(0.8989)$ & & $(0.3667)$ & {$[-0.3922]$} \\
\hline \multirow{2}{*}{$\Delta \mathrm{FBMAI}$} & $2.8435^{* * *}$ & 1.8526 & & $-1.7177^{*}$ \\
& $(0.0917)$ & $(0.1735)$ & & {$[-2.6553]$} \\
\hline
\end{tabular}

Note: * Denote significant at $10 \%,{ }^{* *}$ Denote Significant at 5\%, ${ }^{* * *}$ Denote Significant at $1 \%$

The Granger casuality relation among the stocks defined in the table 8 above. Based on the anylisis VECM test, the findings showed that the VECM test succeeded in producing Ect-1 for FBMESI was 1.5663 and it is significant. This shows that the FBMKLCl and FBMAI variables contribute to the longterm Granger's causes to FBMESI. The FBMESI variable in the equation are found to bear the burden of error correction that is scattered from short-term equilibrium. This is to achieve a balance in the long run and to demonstrate the integrity of FBMESI to the established model. The value of Ect-1 coefficients in this study can also reflect the speed of adjustment to achieve a balance in the long run. A total of 156.6 percent of the adjustments were made during the lag period 1 to achieve a long-term balance. In addition, the value of Ect-1 for FBMAl is -1.7177 and it is significant. This means the 
INTERNATIONAL JOURNAL OF ACADEMIC RESEARCH IN BUSINESS AND SOCIAL SCIENCES Vol. 9, No. 7, July, 2019, E-ISSN: 2222-6990 @ 2019 HRMARS

FBMESI and FBMKLCI variables play a role as a contributor to the long-term Granger to FBMAI. The findings also show that the FBMAl variables in the equation bear the burden of error correction that is scattered from short-term balance aimed at achieving equilibrium in the long run and successfully demonstrating FBMAl's keenity to the established model.

However, the results of the study have shown that there is no long-term causal relationship for the FBMKLCl variable following the value of Ect-1 is -0.13046 and it is not significant. The conclusions from this finding show that $\mathrm{FBMKLCl}$ and $\mathrm{FBMAl}$ variables act as the cause of long-term Granger to FBMESI. Similarly with the FBMESI and FBMKLCI variables which are the long-term causes of Granger to FBMAI. However, there was no long-term Granger relationship between FBMESI and FBMAI with FBMKLCI. In addition, it can be concluded that the FBMESI and FBMAI variables are endogenous variables to the modeled equations. Based on table 8 also, it is arguable that $\mathrm{FBMKLCl}$ is a contributor to the short term Granger to FBMESI, FBMESI and FBMAI variables. The results also show that FBMESI and FBMAI variables are not a cause of short-term Granger on FBMKLCI.

Table 9: VECM Model Diagnostic Test and Period of Structure Change Test

\begin{tabular}{|l|c|c|c|}
\hline \multicolumn{1}{|c|}{ Test } & Statistic Value & p Value & Result \\
\hline Jarque Bera & 1.0833 & 0.5818 & $/$ \\
\hline LM & 5.9876 & 0.7412 & $/$ \\
\hline White Hetero & 67.4628 & 0.9063 & $/$ \\
\hline Max LR F. Statistic & 2.1594 & 0.5950 & $/$ \\
\hline Max Wald F. Statistic & 6.4782 & 0.5950 & / \\
\hline
\end{tabular}

Note: / shows no problem with diagnostic criteria.

The data in table 9 shows that they are normally scattered and are not significant for the established VECM model. The result of this normality distribution is based on the use of Jarque-Bera (JB) test. While Autoregressive test results using the Serial Correlation LM Test indicates that the null hypothesis failed to be rejected at the $p<0,0$ significance level. This shows that the results of the study are not significant. This result illustrates that the error is white noise with min being zero and variance is in constant value. The results of this study also show that the developed VECM model does not have autocorrelation problems which may result in the problem of specification error in the VECM model.

White Hetero test analysis using the Chi Square statistic method shows that there is no effect of the heteroscedasticity problem in the established VECM model. This description is based on the probability value $(P)$ value greater than the value of $p=0.05$. The result of this analysis shows that the null hypothesis is accepted. Based on these findings, the established VECM model is appropriate for the purpose of basic formation.

\section{Conclusion}

The main objective of this study is to investigate the integration among Islamic and Conventional Stocks Market in Malaysia. From the result of the series of test and analysis above, it shows that there is a significant correlation in the long-term relation between FTSE Bursa Malaysia Emas Syariah Index (FBMESI) with FTSE Bursa Malaysia KLCI (FBMKLCI) and FTSE Bursa Malaysia Ace Index (FBMAI). Data 
analysis also shows that there is a direct short-term Granger causality link between FTSE Bursa Malaysia Emas Syariah Index (FBMESI) to FTSE Bursa Malaysia KLCl (FBMKLCl) and FTSE Bursa Malaysia Emas Syariah Index (FBMESI) to FTSE Bursa Malaysia Ace Index (FBMAI). Therefore, it can be concluded that as a result of these findings, investors do not need to diversify their investments in Malaysia in the long run as both the Islamic and Conventional stock markets as well as in the Main Market and ACE are integrated with each other. These finding are in line with recent research on the integration of Islamic and conventional stock markets in Bursa Malaysia as done by Umairah and Mansur (2017) where it was found that a high correlation between the Islamic stock market in Bursa Malaysia and investors did not need to diversify their investments on Bursa Malaysia but could refine their investments in the global market to obtain higher investment benefits. But in the short term, investors may choose to diversify their investments accordingly to maximize returns.

\section{References}

Adam, A. M., \& Tweneboah, G. (2008). Macroeconomic Factors and Stock Market Movement: Evidence from Ghana. SSRN Electronic Journal.

Albaity, M. \& Ahmad, R. (2009). A Comparative Analysis of the Firm Specific Determinants of Syariah Compliant Versus Non-Syariah Compliant Firms in Bursa Malaysia. Asian Journal of Business and Accounting , 4(1), 59-84.

Alexakis, C., Pappas,V., Tsikouras A. (2015). Long Run Asymmetrics Relationships Between Islamic and Conventional Equity Indices. Economic Working Paper Series. 2015/002. Lancaster University Management School.

Auzairy, N. A., Ahmad, R., Ho, C. S. F. Ho \& Sapian, R. Z. Z. (2012). Integration of Asian Stock Markets. International Journal of Social, Behavioral, Educational, Economic, Business and Industrial Engineering. 6(12), 3503-3509.

Chan, S. G. \& Abd Karim, M.Z. (2005). Stock Price Integration in Malaysian Stock Market. Thammasat Economic Journal, 23(3), 124-135.

Darrat, A. F., Elkhal, K. \& Hakim S. (2000). On the Integration of Emerging Stock Markets in the Middle East. Journal of Economic Development, 25, 119 - 129.

Engle, R. F., \& Granger, C. W. (1987). Co-Integration and Error-Correction: Representation, Estimation, and Testing. Econometrica, 55(2), 251.

Eun, C. S., Lee, K., \& Wang, Q. (2014). Stock Market Integration at Home. KAIST College of Business Working Paper Series No. 2014-012. Available at SSRN: https://ssrn.com/abstract=2500611 or http://dx.doi.org/10.2139/ssrn.2500611

Global Islamic Financial Report. (2010). Islamic Fund Product, 56-55. Retrieved from http://www.gifr.net/gifr2010/index.html.

Goldstien, M. \& Mussa, M. (1993). The Integration of World Capital Markets. IMF Working Papers. Economic and Social Review, 26(2), 131 - 147.

Grubel H. (1968). International Diversified Portfolio: Welfare Gains and Capital Flows. American Economic Review, 58, 1299 - 1314.

Hanna, M. (1999). A Nineties Perspective on International Diversification. Financial Services Review, $8(1), 37-45$. 
INTERNATIONAL JOURNAL OF ACADEMIC RESEARCH IN BUSINESS AND SOCIAL SCIENCES

Vol. 9, No. 7, July, 2019, E-ISSN: 2222-6990 @ 2019 HRMARS

Hussin, M. Y., Muhammad F., Razak, A. A., Mahjom, N., Hadi, F. S. (2013) Pasaran Modal Islam di Malaysia: Mengembang atau Menguncup. Jurnal Perspektif, 5(2), 1-14.

Hussin, M.Y., Yusof, Y.A., \& Muhammad, F., Razak, A. A., Hashim, E. \& Marwan, N. F. (2013) The Integration of Islamic Stock Market:Does a Problem for Investors?. Labuan E-Journal Muamalat and Society, 7, 17 - 27.

Iqbal, M.S., Kouser, R., Azeem, M. (2013). Conventional and Islamic Anomalies in Karachi Stock Exchange. Sci.Int. Lahore, 25(4), 999 - 1007.

Johansen, S. and Juselius, K. (1990). Maximum Likelihood Estimation and Inference on Cointegration with Applications to Demand for Money. Oxford Bulletin of Economics and Statistics. 52(2), 169-210.

Kassim, S. H. (2013). The Global financial Crisis and The Integration of Islamic Stock Markets in Developed and Developing Countries. Asian Academy of Management Journal of Accounting \& Finance, 9 (2), 75-94.

Lee, G., \& Jeong, J. (2014). Global Financial Crisis and Stock Market Integration Between Northeast Asia and Europe. Review of European Studies, 6(1), 61-75.

Levy, H. \& Sannat, M. (1970). International Diversification on Investment Portfolios. American Economic Review, 60, 668-675.

Majdoub, J., Mansour, W., \& Jouini, J. (2016). Market Integration between Conventional and Islamic Stock Prices. The North American Journal of Economics and Finance, 37, 436-457.

Marashdeh, H., \& Shrestha, M., (2010). Stock Market Integration in the GCC Countries. International Research Journal of Finance and Economics, 37, 104-114.

Marjan, N. \& Mansur, M. (2014). Integration and Comovement of Developed and Emerging Islamic Stock Markets: A Case Study Of Malaysia. Munich Personal RePEc Archive Paper No. 58799 Posted 24 Retrieved from https://mpra.ub.unimuenchen.de/58799/1/MPRA_paper_58799.pdf.

Majdoub, J., Mansour, W., \& Jouini, J. (2016). Market integration between conventional and Islamic stock prices. The North American Journal of Economics and Finance, 37, 436-457.

Mohan R. (2005). Globalisation, Financial Markets and the Operation of Monetary Policy in India. Bank for International, Globalisation and Monetary Policy in Emerging Markets BIS Paper No. 23. Retrieved from https://www.bis.org/publ/bppdf/bispap23.pdf.

Osterwald-Lenum, M. (1992). A Note with Quantiles of the Asymptotic Distribution of the Maximum Likelihood Cointegration Rank Test Statistics1. Oxford Bulletin of Economics and Statistics, 54(3), 461-472.

Pranata, N. \& Nurzanah, N. (2015) Conventional and Islamic Indices in Indonesia: A Comparison on Performance, Volatility, and the Determinants. Indonesian Capital Market Review. 7 (2), 113127.

Ramdhan, N. A., Mohamed Yousop, N. L., Ahmad, Z., \& Abdullah, H. N. M., (2016). Malaysia Stock Market Integration: The Effect of Leader and Emerging Market. Journal of Advance Research in Business and Management Studies. 2(1), 1-10.

Tai, C. (2007). Market Cointegration and Contagion: Evidence from Asian Emerging Stock and Foreign Exchange Markets. Emerging Markets Review, 8(4), 264 - 283. 
INTERNATIONAL JOURNAL OF ACADEMIC RESEARCH IN BUSINESS AND SOCIAL SCIENCES

Vol. 9, No. 7, July, 2019, E-ISSN: 2222-6990 @ 2019 HRMARS

Wong, H. T. \& Chen, Z. (2011). Integration Analysis of The People's Republic of China Stock Markets. Labuan Bulletin of International Business and Finance, 9, 24 - 43.

Wooi, H. C. (2007). Integrasi Pasaran-Pasaran Saham di Negara APEC: Satu Kajian Empirikal. International Journal of Management Studies, 14(2), 127 - 142.

Yusof R. M., Majid, M. S. A. \& Razali, A. N. (2006). Macroeconomic variables and stock returns in the post 1997 Financial Crisis: an application of the ARDL model. Proceedings of the 6th Global Conference on Business \& Economics, GUTMAN Conference Center, USA. 